\title{
Passion, grit, and mindset in undergraduate sport sciences students
}

\author{
Roberta Frontini a,b, ", Hermundur Sigmundsson ${ }^{c, d}$, Raul Antunes ${ }^{a, b, e}$, Ana Filipa Silva ${ }^{\text {f,g }}$, \\ Ricardo Lima $^{\text {g,h }}$, Filipe Manuel Clemente ${ }^{\text {h,i }}$ \\ ${ }^{a}$ Center for Innovative Care and Health Technology (ciTechCare), Polytechnic of Leiria, Leiria, Portugal \\ ${ }^{\mathrm{b}}$ CIEQV - Life Quality Research Centre, Polytechnic of Leiria, 2411, Leiria, Portugal \\ ${ }^{\mathrm{c}}$ Department of Psychology, Norwegian University of Science and Technology, Norway \\ ${ }^{\mathrm{d}}$ Reykjavik University, Reykjavik, Iceland \\ e School of Education and Social Sciences (ESECS), Polytechnic Institute of Leiria, Portugal \\ ${ }^{\mathrm{f}}$ N2i, Polytechnic Institute of Maia, 4475-690, Maia, Portugal \\ ${ }^{\mathrm{g}}$ The Research Centre in Sports Sciences, Health Sciences and Human Development (CIDESD), Vila Real, 5001-801, Portugal \\ ${ }^{\mathrm{h}}$ Escola Superior Desporto e Lazer, Instituto Politécnico de Viana Do Castelo, Rua Escola Industrial e Comercial de Nun'Álvares, 4900-347, Viana Do Castelo, Portugal \\ ${ }^{\mathrm{i}}$ Instituto de Telecomunicações, Delegação da Covilhã, Lisboa, 1049-001, Portugal
}

\section{A R T I C L E I N F O}

\section{Keywords:}

Sports sciences

Achievement

University

Students

Performance

\begin{abstract}
A B S T R A C T
The aim of this study was two-fold: (i) to compare passion, grit and mindset between sexes; and (ii) to analyze the relationships between passion, grit and mindset. Fifty-eight men (age: $20.10 \pm 2.70$ years old) and forty-eight women (age: $19.27 \pm 4.10$ years old) sports sciences undergraduate students voluntarily participated in this study. A cross-sectional survey design was followed. The passion scale, grit scale and mindset scale were provided to participants. Comparisons in the passion, grit and mindset items revealed no significant differences between sexes ( $\mathrm{p}>0.05$ ). Relationships between passion, grit and mindset were tested. Overall (both sexes considered), correlations presented small magnitudes in the pair's passion* grit ( $\mathrm{r}=0.28 ; 95 \% \mathrm{CI}[-0.07 ; 0.31]$; $\mathrm{p}$ $=0.004)$, passion*mindset $(\mathrm{r}=0.203 ; 95 \% \mathrm{CI}[0.01 ; 0.38] ; \mathrm{p}=0.043)$ and grit*mindset $(\mathrm{r}=0.06 ; 95 \% \mathrm{CI}[-0.14$; $0.25] ; p=0.574$ ). As conclusions, the present study did not find significant differences in passion, grit and mindset between sexes in undergraduate sports sciences students. Additionally, it was verified that relationships between passion, grit and mindset are small in this population.
\end{abstract}

\section{Introduction}

Passion, grit and mindset are three important concepts in sports psychology (Duckworth, Kirby, Tsukayama, Berstein, \& Ericsson, 2011; Dweck, 2008; Vallerand \& Miquelon, 2007). In fact, research has suggested that they may be critical in helping an individual become excellent in different areas, themes, and skills. Moreover, some studies found meaningful correlations between these variables in sports populations, namely significant correlations between passion and grit (e.g., Sigmundsson, Clemente, \& Loftesnes, 2020).

For instance, passion is important to understand the drop out of athletes, because passionate athletes are less likely to dropout and more likely to achieve a specific goal (Vallerand \& Miquelon, 2007). Grit is also important to accomplish certain objectives, reflecting the passion and perseverance for long-term goals (Hernández, Moreno-Murcia, Cid,
Monteiro, \& Rodrigues, 2020). Finally, the mindset was also found to be crucial by playing an important role in motivation and helping individuals to have a coping-oriented answer to challenges (Dweck, 1986; Dweck, Chiu, \& Hong, 2009). However, it is still important to better understand the relationship between these three variables in different populations, not only sportsmen. Moreover, it is important to understand whether the two genders differ in these variables. This is important in order to create specific and individualized strategies.

\subsection{Passion}

Passion has been studied over the years in very different areas, including sports psychology. It has been described as a solid desire toward an activity that an individual may understand as important, investing time and energy in something he/she likes (Vallerand, 2010).

\footnotetext{
* Corresponding author. Center for Innovative Care and Health Technology (ciTechCare), Polytechnic of Leiria, R. de Santo André, 2410, Leiria, Portugal.

E-mail addresses: roberta.frontini@ipleiria.pt (R. Frontini), hermundur.sigmundsson@ntnu.no (H. Sigmundsson), raul.antunes@ipleiria.pt (R. Antunes), anafilsilva@gmail.com (A.F. Silva), ricardo.lima@esdl.ipvc.pt (R. Lima), filipe.clemente5@gmail.com (F.M. Clemente).
} 
Indeed, usually, athletes passionate about their sports invest more time and energy into their practice (Eklund \& Tenenbaum, 2014). Passion is an important variable and, in line with the well-known self-determination theory (Ryan \& Deci, 2002).

This theory exemplifies a comprehensive framework for the study of human motivation, proposing that the extent to which any of three psychological needs (autonomy, competence, and relatedness) is unsupported within a social context will have an important harmful influence on wellbeing in that setting (Deci \& Ryan, 2008). Thus, if an individual spends regular time in an activity he/she is passionate about, this activity may become part of the individuals' identity (Eklund \& Tenenbaum, 2014; Vallerand et al., 2006). This usually happens in particular sports which became the identity of the player, with the general public not being able to separate both. Thus, passion may be considered as an important motivator behind a specific activity, or passion for achievement (Sigmundsson, Haga, \& Hermundsdottir, 2020a). Moreover, passion is important both for happiness and self-growth (Vallerand, 2008). Vallerand, Donahue, and Lafreniere (2011) argue that there are two types of passion: harmonious passion and obsessive passion. These authors argue that only harmonious passion will allow the activity to become part of one's identity since it is a powerful desire to participate in an activity freely, whereas in obsessive passion the individual is dominated by the activity. Although this division may be found in literature, in this article we will not focus on these two types of passion separately.

\subsection{Grit (perseverance)}

Grit is a relatively new concept that received little attention (From, Olesen, \& Thomsen, 2020). Nevertheless, it is considered of utmost importance for the pursuit of long-term goals, even when they are challenging (Duckworth et al., 2011) and despite the possible failure of progress (Sigmundsson et al., 2020a). Grit is defined as a trait associated with deliberate performance (Eskreis-Winkler, Shulman, Beal, \& Duckworth, 2014) involving working hard towards challenging objectives (Sigmundsson et al., 2020a). It has been argued that grit may be a better predictor of success than cognitive ability (Duckworth, 2013). Grit incorporates passion and perseverance (Duckworth \& Quinn, 2009) and has become crucial to understand life success in different areas (Hernández et al., 2020) and populations (e.g., Eskreis-Winkler et al., 2014; From et al., 2020). In fact, several studies attempted to demonstrate the importance of grit in achieving positive outcomes (Hernández et al., 2020) and productivity (Hodge, Wright, \& Bennett, 2018). A recent study with elite athletes showed that they scored higher on grit compared to the control group (From et al., 2020). Moreover, research has found that grit is related to better engagement in wheelchair basketball players (Martin, Byrd, Watts, \& Dent, 2015).

Higher scores on grit have also been linked with higher levels of mental well-being and a growth-oriented mindset (Kannangara et al., 2018). Recently, investigations showed the importance of grit to explain academic performance (Hernández et al., 2020). However, because the concept of grit has faced several criticisms, further research with this concept is warranted (Rutberg, Nyberg, Castelli, \& Lindqvist, 2020).

\subsection{Mindset}

Mindset is defined as a set of beliefs about the nature of human attributes (Dweck, 2012). Research has shown the positive impact of mindset. For instance, mindset may influence how a student will perform a challenging task (Glerum, Loyens, \& Rikers, 2020). This may be due to the fact that individuals believing that their qualities may be developed usually seek challenging learning opportunities (Dweck, 2012). In fact, there are two forms of mindset: a growth and a fixed mindset (Dweck, 2008). People with a growth mindset believe that it is possible to change human attributes whereas people with a fixed mindset consider that human attributes are fixed and permanent
(Sigmundsson et al., 2020a). Although for years, in sports, athletes were considered to have a "natural" talent (Dweck, 2008), research has shown that mindset may play an important role. It is important to note that mindset is built from prior experiences especially with significant people such as parents, siblings or teachers (Dweck, 2008).

\subsection{Gender differences}

As previously stated, gender differences are crucial in order to create specific and individualized strategies. This is even more important when considering that literature has found differences in these variables. This may be due to the fact that passion, grit and mindset are mostly studied in sports sample and, in sports, there still exists gender differences (Eriksen, 2021).

For instance, gender differences have been found in passion, with females presenting higher scores when compared to men (Sigmundsson, 2021). Regarding grit, studies have found mixed results. While some studies found that females usually score higher on grit compared to men (Kannangara et al., 2018; Schmidt, Nagy, Fleckenstein, Möller, \& Retelsdorf, 2018), other studies found no differences (Hodge et al., 2018). Regarding mindset, a recent study found no gender differences (Sigmundsson, 2021) which is in line with literature in the field (Macnamara \& Rupani, 2017). Moreover, when searching for gender differences in the correlation between variables, differences were also found. For instance, studies have found that males present a higher correlation between passion and grit especially compared to the not so high passion - mindset and grit - mindset. On the contrary, females present a relationship quite similar between the three factors (Sigmundsson, 2021).

Considering the importance of better understand these three variables altogether, the purpose of this study was twofold: (i) to compare passion, grit and mindset between sexes; (ii) to analyze the relationships between passion, grit and mindset. Because this is an exploratory study, no previous hypothesis where made.

\section{Methods}

\subsection{Participants}

Fifty-eight men (age: $20.10 \pm 2.70$ years old) and forty-eight women (age: $19.27 \pm 4.10$ years old) sports sciences undergraduate students voluntarily participated in this study. The participants belong to two Sports Sciences Universities of Portugal. All students were in the first or second year of a three-year bachelor's degree. Participants were tested on the passion scale, grit scale and mindset scale. The information about the study design, scales and procedures were first provided.

\subsection{Experimental approach}

A cross-sectional survey design was followed. The passion scale, grit scale and mindset scale were provided to participants. The participants filled the questionnaires at an individual table and cheer, only after being informed about the procedures and the scales and questionnaires. The questionnaires were fulfilled in a random order between the participants, with the following sequences: (a) passion-grit-mindset; (b) passion-mindset-grit; (c) grit-passion-mindset; (d) grit-mindset-passion; (e) mindset-passion-grit; (f) mindset-grit-passion. The questionnaires were applied in February of 2020 (beginning of the second semester of the academic year). Before filled the passion, grit and mindset scales, participants indicated their age, sex and education level.

\subsection{Measures}

\subsubsection{Passion scale}

In order to assess the participant's level of passion, the Portuguese version of The Passion scale (Sigmundsson et al., 2020a) was used. The 5-point Likert scale is one of the most common (Likert, 1932) and was 
used for possible comparison to other important factors related to passion. For an overview of the 8-items see Table 1 . The maximum score on this scale is 5 (extremely passionate) and the lowest is 1 (not at all passionate). Passion showed good internal consistency Cronbach's alpha value .86 . Passion showed high test-retest reliability, with an ICCs between test and retest total scores was $0.92(\mathrm{~N}=21$, mean age 23.67, SD $=2.41$ ). Construct validity: Pearson correlation coefficient between total score Passion and Grit S Scale were $\mathrm{r}=0.39$ for adults, mean age $21.23(\mathrm{SD}=3.45)(\mathrm{N}=107)$ (Sigmundsson et al., 2020a).

\subsubsection{Grit scale}

To assess the participant's level of grit, the Portuguese version of the short grit scale - Grit S (Duckworth \& Quinn, 2009). - was used. The scale comprises eight items, using a 5-point Likert scale with items rated in terms of how much the item is "true" for the respondent (1 - not like me at all and 5 - very much like me). The measure includes two subscales of four items each; Consistency of Interest (COI) and Perseverance of Effort (POE). Table 2 presents an overview of the 8-items of the scale. Grit-S showed good internal consistency several times, $\alpha=0.82$ and $\alpha=$ 0.84 (Duckworth \& Quinn, 2009, p. 170). The study provided evidence for the predictive validity, consensual validity, and test-retest stability of the Grit-S.

\subsubsection{Mindset scale}

Finally, to assess students' entity and incremental conceptions of intelligence a Portuguese version of the Theories of intelligence scale (Dweck, 1999) (TIS) was used. In the present study, the self-form for adults of this measure was used to ensure that the participants focused on their ideas about their own intelligence (and not their ideas about people in general). This scale consists of several subscales with items rated on a 6-point Likert-type scale, from 1 (Strongly Agree) to 6 (Strongly Disagree). The items included, differ between those associated with an entity theory (i.e., fixed mindset) and those associated with an incremental theory (i.e., growth mindset). For instance, an entity theory item can be "You have a certain amount of intelligence and you really can't do much to change it", whereas an incremental theory item can be "You can always substantially change how intelligent you are". To get a meaningful score that indicates which mindset the participant holds, the incremental scale items are reversed. As a result, when all items are summed, the higher average scores indicate a greater amount of

Table 1

Descriptive statistics (mean \pm standard deviation [SD]) of the scores in the Passion questionnaire.

\begin{tabular}{|c|c|c|c|c|}
\hline & $\begin{array}{l}\text { Men }(\mathrm{N}= \\
58) \\
\text { Mean } \pm \mathrm{SD}\end{array}$ & $\begin{array}{l}\text { Women }(\mathrm{N} \\
=42) \\
\text { Mean } \pm \mathrm{SD}\end{array}$ & $p$ & $\begin{array}{l}\mathrm{r} \mid \\
\text { magnitude }\end{array}$ \\
\hline $\begin{array}{l}\text { I have an area/theme/skill I } \\
\text { am really passionate for }\end{array}$ & $4.6 \pm 0.5$ & $4.5 \pm 0.7$ & 0.813 & $\begin{array}{l}-0.024 \\
\text { trivial }\end{array}$ \\
\hline $\begin{array}{l}\text { I would like to use much time } \\
\text { to become good in that } \\
\text { area/theme/skill }\end{array}$ & $4.5 \pm 0.6$ & $4.5 \pm 0.6$ & 0.724 & $\begin{array}{l}-0.035 \\
\text { trivial }\end{array}$ \\
\hline $\begin{array}{l}\text { I think I could be an expert in } \\
\text { one area/theme/skill }\end{array}$ & $4.6 \pm 0.5$ & $4.4 \pm 0.6$ & 0.182 & $\begin{array}{l}-0.133 \\
\text { trivial }\end{array}$ \\
\hline $\begin{array}{l}\text { I have a passion enough to } \\
\text { become very good in the } \\
\text { area/theme/skill I like }\end{array}$ & $4.5 \pm 0.6$ & $4.6 \pm 0.6$ & 0.195 & $\begin{array}{l}-0.130 \\
\text { trivial }\end{array}$ \\
\hline $\begin{array}{l}\text { I work hard enough to fulfil } \\
\text { my goals }\end{array}$ & $3.8 \pm 0.8$ & $4.0 \pm 0.6$ & 0.247 & $\begin{array}{l}-0.116 \\
\text { trivial }\end{array}$ \\
\hline $\begin{array}{l}\text { I have burning passion for } \\
\text { some areas/theme/skills }\end{array}$ & $4.2 \pm 0.7$ & $4.3 \pm 0.7$ & 0.614 & $\begin{array}{l}-0.050 \\
\text { trivial }\end{array}$ \\
\hline $\begin{array}{l}\text { I use a lot of time on the } \\
\text { projects I like }\end{array}$ & $4.1 \pm 0.7$ & $4.1 \pm 0.7$ & 0.886 & $\begin{array}{l}-0.014 \\
\text { trivial }\end{array}$ \\
\hline $\begin{array}{l}\text { My passion is important for } \\
\text { me }\end{array}$ & $4.6 \pm 0.6$ & $4.8 \pm 0.5$ & 0.096 & $\begin{array}{l}-0.167 \\
\text { trivial }\end{array}$ \\
\hline Mean & $4.5 \pm 0.6$ & $4.5 \pm 0.5$ & 0.960 & $\begin{array}{l}-0.005 \\
\text { trivial }\end{array}$ \\
\hline Total Passion Score & $35.0 \pm 3.5$ & $35.3 \pm 3.1$ & 0.739 & $\begin{array}{l}-0.033 \\
\text { trivial }\end{array}$ \\
\hline
\end{tabular}

Table 2

Descriptive statistics (mean \pm standard deviation [SD]) of the scores in the Grit questionnaire.

\begin{tabular}{|c|c|c|c|c|}
\hline & $\begin{array}{l}\text { Men }(\mathrm{N}= \\
56) \\
\text { Mean } \pm S D\end{array}$ & $\begin{array}{l}\text { Women }(\mathrm{N} \\
=39) \\
\text { Mean } \pm \text { SD }\end{array}$ & $p$ & $\begin{array}{l}\mathrm{r} \mid \\
\text { magnitude }\end{array}$ \\
\hline $\begin{array}{l}\text { New ideas and projects } \\
\text { sometimes distract me from } \\
\text { previous ones }\end{array}$ & $2.7 \pm 1.0$ & $2.7 \pm 2.4$ & 0.980 & $\begin{array}{l}-0.003 \\
\text { trivial }\end{array}$ \\
\hline $\begin{array}{l}\text { Setbacks dont't discourage } \\
\text { me }\end{array}$ & $3.9 \pm 0.7$ & $3.9 \pm 0.7$ & 0.973 & $\begin{array}{l}-0.003 \\
\text { trivial }\end{array}$ \\
\hline $\begin{array}{l}\text { I have been obsessed with a } \\
\text { certain idea or project for a } \\
\text { short time but later lost } \\
\text { interest }\end{array}$ & $3.0 \pm 1.1$ & $2.9 \pm 1.1$ & 0.702 & $\begin{array}{l}-0.039 \\
\text { trivial }\end{array}$ \\
\hline I am a hard worker. & $4.0 \pm 0.7$ & $4.2 \pm 0.6$ & 0.376 & $\begin{array}{l}-0.090 \\
\text { trivial }\end{array}$ \\
\hline $\begin{array}{l}\text { I often set a goal but later } \\
\text { choose to pursue a different } \\
\text { one }\end{array}$ & $3.3 \pm 1.2$ & $3.4 \pm 1.0$ & 0.645 & $\begin{array}{l}-0.047 \\
\text { trivial }\end{array}$ \\
\hline $\begin{array}{l}\text { I have difficulty maintaining } \\
\text { my focus on projects that } \\
\text { take more than a few } \\
\text { months to complete }\end{array}$ & $3.1 \pm 1.1$ & $3.5 \pm 1.1$ & 0.082 & $\begin{array}{l}-0.179 \\
\text { trivial }\end{array}$ \\
\hline I finish whatever I begin & $4.2 \pm 0.6$ & $4.3 \pm 0.7$ & 0.688 & $\begin{array}{l}-0.041 \\
\text { trivial }\end{array}$ \\
\hline I am diligent & $3.9 \pm 0.7$ & $3.9 \pm 0.7$ & 0.796 & $\begin{array}{l}-0.026 \\
\text { trivial }\end{array}$ \\
\hline Mean & $3.6 \pm 0.5$ & $3.7 \pm 0.5$ & 0.302 & $\begin{array}{l}-0.106 \\
\text { trivial }\end{array}$ \\
\hline Grit Score & $28.1 \pm 3.4$ & $28.9 \pm 3.7$ & 0.398 & $\begin{array}{l}-0.086 \\
\text { trivial }\end{array}$ \\
\hline
\end{tabular}

incremental beliefs about intelligence i.e. growth mindset. The reliability data for the scale comes from Dweck et al. (1995) and is based on the 8 -item scale. The scale shows good internal consistency ( $\alpha=0.85$ ) and test-retest reliability at 2-weeks $(r=0.80)$. The scale also shows a good construct validity with scores predicting meaningful relationship with several variables (Dweck et al., 1995).

\subsection{Statistical procedures}

Descriptive data was presented in the form of mean and standard deviation. Participants were excluded in the case of not fulfilling any of the questionnaires. No case occurred. Items with no answer were classified as missing cases in the statistical software. Preliminary analysis revealed normality of the data $(p>0.05)$, but not homogeneity ( $\mathrm{p}<$ 0.05 ). Due to the absence of homogeneity, the non-parametric MannWhitney $U$ test was executed to analyze the variations of scores between men and women. To determine the effect size the formula of $r=\frac{z}{\sqrt{N}}$ was used, after the Mann-Whitney (Fritz, Morris, \& Richler, 2012). The magnitude of effect size was determined based on the following thresholds (Ferguson, 2009): [0.0; 0.2[ trivial; [0.2; 05[ minimum; [0.5; 0.8 [ moderate; $>0.8$, strong. The correlations were tested with the Pearson R test, since the data was normal. The magnitude of correlations were classified as follows: $0.00-0.10$ trivial; $0.11 ; 0.29$, small; 0.30 ; 0.49 , moderate; $0.50 ; 0.69$, large; 0.70 ; 089, very large; and 0.90-1.00, nearly perfect. The statistical procedures were executed in the SPSS software (version 26.0, IBM, Chicago, USA) for a $p<0.05$.

\section{Results}

Descriptive statistics of answers provided to passion, grit and mindset questionnaires can be found in Tables 1-3, respectively. Analysis of variation between sexes did not found significant differences in the Passion scores. Moreover, none of the differences had meaningful effects.

Comparisons in the Grit items revealed no significant differences between sexes. Moreover, the only trivial magnitude of changes was 
Table 3

Descriptive statistics (mean \pm standard deviation [SD]) of the scores in the Mindset questionnaire.

\begin{tabular}{|c|c|c|c|c|}
\hline & $\begin{array}{l}\text { Men }(\mathrm{N}= \\
56) \\
\text { Mean } \pm \mathrm{SD}\end{array}$ & $\begin{array}{l}\text { Women }(\mathrm{N} \\
=41) \\
\text { Mean } \pm \mathrm{SD}\end{array}$ & $\mathrm{p}$ & $\begin{array}{l}\mathrm{r} \mid \\
\text { magnitude }\end{array}$ \\
\hline $\begin{array}{l}\text { You have a certain amount of } \\
\text { intelligence, and you can't } \\
\text { really do much to change it }\end{array}$ & $3.9 \pm 1.5$ & $3.8 \pm 1.2$ & 0.523 & $\begin{array}{l}-0.065 \\
\text { trivial }\end{array}$ \\
\hline $\begin{array}{l}\text { Your intelligence is } \\
\text { something about you that } \\
\text { you can't change very } \\
\text { much }\end{array}$ & $4.0 \pm 1.5$ & $3.8 \pm 1.2$ & 0.446 & $\begin{array}{l}-0.077 \\
\text { trivial }\end{array}$ \\
\hline $\begin{array}{l}\text { No matter who you are, you } \\
\text { can significantly change } \\
\text { your intelligence level }\end{array}$ & $5.0 \pm 0.8$ & $5.0 \pm 0.7$ & 0.788 & $\begin{array}{l}-0.027 \\
\text { trivial }\end{array}$ \\
\hline $\begin{array}{l}\text { To be honest, you can't really } \\
\text { change your basic } \\
\text { intelligence }\end{array}$ & $4.1 \pm 1.5$ & $4.2 \pm 1.5$ & 0.708 & $\begin{array}{l}-0.038 \\
\text { trivial }\end{array}$ \\
\hline $\begin{array}{l}\text { You can always substantially } \\
\text { change how intelligent you } \\
\text { are }\end{array}$ & $4.9 \pm 0.8$ & $4.8 \pm 0.6$ & 0.595 & $\begin{array}{l}-0.054 \\
\text { trivial }\end{array}$ \\
\hline $\begin{array}{l}\text { You can learn new things, but } \\
\text { you can't really change } \\
\text { your basic intelligence }\end{array}$ & $3.9 \pm 1.4$ & $4.1 \pm 1.3$ & 0.228 & $\begin{array}{l}-0.122 \\
\text { trivial }\end{array}$ \\
\hline $\begin{array}{l}\text { No matter how much } \\
\text { intelligence you have, you } \\
\text { can always change it quite a } \\
\text { bit }\end{array}$ & $5.0 \pm 0.8$ & $5.0 \pm 0.7$ & 0.904 & $\begin{array}{l}-0.012 \\
\text { trivial }\end{array}$ \\
\hline $\begin{array}{l}\text { You can change your basic } \\
\text { intelligence level } \\
\text { considerably }\end{array}$ & $4.9 \pm 0.7$ & $4.8 \pm 0.7$ & 0.556 & $\begin{array}{l}-0.060 \\
\text { trivial }\end{array}$ \\
\hline Mean & $4.6 \pm 0.9$ & $4.7 \pm 0.7$ & 0.380 & $\begin{array}{l}-0.089 \\
\text { trivial }\end{array}$ \\
\hline Mindset Score & $35.7 \pm 6.5$ & $35.5 \pm 4.9$ & 0.916 & $\begin{array}{l}-0.011 \\
\text { trivial }\end{array}$ \\
\hline
\end{tabular}

found between sexes.

Analysis of variation between sexes was conducted considering the mindset questionnaire. No significant differences were found, and all the changes presented trivial effect sizes.

Relationships between passion, grit and mindset were tested (Fig. 1). Overall (both sexes considered), correlations presented small magnitudes in the pair's passion* grit $(\mathrm{r}=0.28 ; 95 \%$ CI $[-0.07 ; 0.31] ; p=$ 0.004).

\section{Discussion}

The focus of this study was to compare passion, grit, and mindset between sexes as well as to analyze the relationships between these

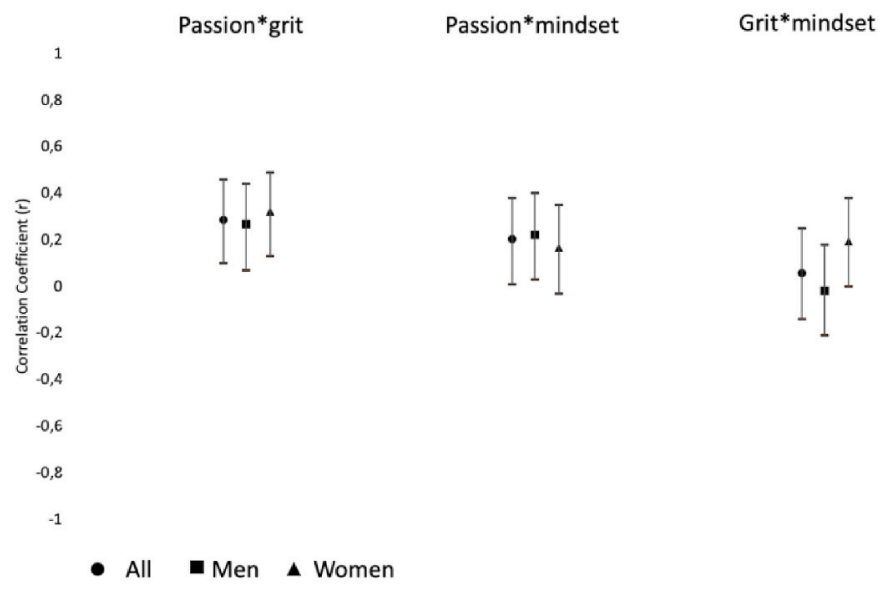

Fig. 1. Correlation coefficient [mean, 95\%CI] between passion, grit, and mindset in all undergraduate and split by sexes. three variables in sports sciences undergraduate students. Correlations presented only small magnitudes in the pair's passion*grit and grit*mindset. The results also indicate that there were no differences between sexes in the three variables analyzed. These results are important considering there is a lack of studies regarding the relationship between these variables (Sigmundsson et al., 2020a). Thus, research in the area is needed.

The sample of the present study comprised 58 men (age: $20.10 \pm 2.70$ years old) and 48 women (age: $19.27 \pm 4.10$ years old). Regarding the correlations between variable, they presented small magnitudes in the pair's passion*grit $(\mathrm{r}=0.28$; 95\%CI $[-0.07 ; 0.31] ; p=0.004)$, and passion*mindset $(\mathrm{r}=0.203 ; 95 \% \mathrm{CI}[0.01 ; 0.38] ; p=0.043)$. The score for the relationship between passion*grit and passion*mindset is lower than the ones found in Sigmundsson, Haga, and Hermundsdottir (2020b), however, it indicates significant interaction between these variables and indicates that these variables are intertwined. This was not the case for the correlation for grit*mindset which was different from Sigmundsson et al. (2020b). To understanding these results, more detailed knowledge regarding the sample would be required. Particularly it would be important to understand if the participants of the study practice any type of sports (i.e., the fact that they are sports students does not mean they practise any sport). Future studies should be able to recruit larger samples and clearly identify students' physical exercise and sport.

Regarding the scores of the passion scale, analysis of variation between sexes did not found significant differences. The mean of the two sexes was 4.5 (with a SD of 0.6 for males and 0.5 for females). In a sample of university students in Iceland (Sigmundsson et al., 2020a), the mean scores were 4.10 (SD 0.61) and gender differences were found with males reporting higher levels of passion compared to females. It is also important to compare these results with the results of a study on Portuguese football players (Sigmundsson et al., 2020) where the mean score was 4.62 (SD 0.35). These results suggest that participants in the present study presented lower passion levels for a theme/skill/area. This may be due to the fact that this was not a sample of sportsman. In fact, literature has consistently found that passion is an important factor in sports. This sample regarded sports students and not athletes. Thus, this study adds important information and suggests that future studies should be addressed in order to test possible differences between sportsmen and general population samples.

Comparisons in the Grit items also revealed no significant differences between sexes. Moreover, and consistent with the previous result, we found lower scores of grit, with a mean of 3.6 (SD 0.5) for males and 3.7 (SD 0.5) for females. Once more, by comparing with a sample of university students in Iceland (Sigmundsson et al., 2020a), the mean scores were 3.52 (SD 0.57). In the study with Portuguese football players (Sigmundsson et al., 2020) the mean score ranged from 3.78 to 3.99 , suggesting that in the present study participants presented lower grit levels compared to other Portuguese samples. Our results seem to be closer to the study scores of the university students $(\mathrm{H}$. Sigmundsson et al., 2020a) than to those obtained in the study with Portuguese football players (Sigmundsson et al., 2020), which seems to reinforce the role that sports can play in these variables (a practice that not everyone will do, in the context of the sample of university students).

As regards to mindset, no significant differences were found. Scores ranged from 4.6 (SD 0.9) males and 4.7 (SD 0.7) females which, once more, differed from the study of Sigmundsson et al. (2020) with a sample of university students, which presented a mean score of 4.35 (SD 0.95). Cultural and social differences between countries may help explain these results. Lower values were also found in a sample of football players (Sigmundsson et al., 2020) ranging from 4.26 to 4.58.

Considering the results of the sample, and the fact they were university students, it would be interesting to explore if the faculty and area of study chosen by these participants were its first choice. Moreover, it would be interesting to explore the expectations and dreams of these students, what motivates them and how this motivation changes. This is 
particularly important considering that research has shown differences in motivation according to school years (Jacobs \& Newstead, 2000).

This study highlights the importance of considering these three variables. Future studies exploring the nature of passion in this specific context and population is crucial. These results may also have practical implications in universities. It highlights that it might be important to have faculty members involved with the student to better understand their passion and the motivation to keep studying. This may have an important impact on academic involvement and, ultimately, academic performance (Elias, Noordin, \& Mahyuddin, 2010).

\section{Conclusions}

Passion, grit and mindset are three variables usually studied together. However, there are still mixed results and contradictory findings. In the present study, the results revealed no significant differences in passion, grit and mindset between sexes. This may suggest that these qualities are independent of the participants' sex. More participants and studies should be analyzed to explain the values. Moreover, more studies are needed in this area in order to better understand the relationship between these three variables.

Although they cannot be generalized, these results leave some interesting information that should be the focus of attention for professionals and researchers, namely because the absence of gender difference seems to indicate that, in this population, the way passion, grit and mindset are perceived by individuals occurs regardless of gender. This should lead to the fact that the strategies adopted for its promotion, which is so important to increase the levels of adherence and/or maintenance of physical activity and/or sport, are similar for men and women, eventually finding mixed models of participation (for example at the university sports).

\section{CRediT authorship contribution statement}

Roberta Frontini: Conceptualization, Methodology, Software, Writing - review \& editing. Hermundur Sigmundsson: Conceptualization, Methodology, Software, Writing - review \& editing. Raul Antunes: Conceptualization, Methodology, Software, Writing - review $\&$ editing. Ana Filipa Silva: Conceptualization, Methodology, Software, Writing - review \& editing. Ricardo Lima: Conceptualization, Methodology, Software, Writing - review \& editing. Filipe Manuel Clemente: Conceptualization, Methodology, Software, Data curation, Writing - original draft, Writing - review \& editing.

\section{Acknowledgments}

The authors would like to thank Francisco Caleiro for his help in data collection and the conception of databases.

\section{References}

Deci, E. L., \& Ryan, R. M. (2008). Self-determination theory: A macrotheory of human motivation, development, and health. Canadian Psychology/Psychologie Canadienne, 49(3), 182-185. https://doi.org/10.1037/a0012801

Duckworth, A. L. (2013). The key to success? Grit. https://www.ted. com/talks/angela_lee_duckworth_the_key_to_success_grit?language//en\#t-9644.

Duckworth, A., Kirby, T. A., Tsukayama, E., Berstein, H., \& Ericsson, K. A. (2011). Deliberate practice spells success: Why grittier competitors triumph at the National Spelling Bee. Social Psychological and Personality Science, 2(2), 174-181. https://doi. org $/ 10.1177 / 1948550610385872$

Duckworth, A., \& Quinn, P. (2009). Development and validation of the short grit scale (grit-S). Journal of Personality Assessment, 91(2), 166-174. https://doi.org/10.1080/ 00223890802634290

Dweck, C. S. (1986). Motivational processes affecting learning. American Psychologist, 41 (10), 1040-1048.

Dweck, C. S. (2008). Mindset: The new psychology of success.

Dweck, C. S. (2012). Mindsets and human nature: Promoting change in the middle east, the schoolyard, the racial divide, and willpower. American Psychologist, 67(8), 614-622. https://doi.org/10.1037/a0029783
Dweck, C. S., Chiu, C., \& Hong, Y. (2009). Implicit theories: Elaboration and extension of the model implicit theories. Psychological Inquiry, 6(4), 37-41. https://doi.org/ 10.1207/s15327965pli0604

Eklund, R. C., \& Tenenbaum, G. (2014). Encyclopedia of sport and exercise psychology. Sage Publications, Inc.

Elias, H., Noordin, N., \& Mahyuddin, R. H. (2010). Achievement motivation and selfefficacy in relation to adjustment among university students. Journal of Social Sciences, 6(3), 333-339.

Eriksen, I. M. (2021). Teens' dreams of becoming professional athletes: The gender gap in youths' sports ambitions. Sport in Society, 1-15. https://doi.org/10.1080/ 17430437.2021.1891044, 0(0).

Eskreis-Winkler, L., Shulman, E. P., Beal, S. A., \& Duckworth, A. L. (2014). The grit effect: Predicting retention in the military, the workplace, school and marriage. Frontiers in Psychology, 5(FEB). https://doi.org/10.3389/fpsyg.2014.00036

Ferguson, C. J. (2009). An effect size primer: A guide for clinicians and researchers. Professional Psychology: Research and Practice, 40(5), 532-538. https://doi.org/ $10.1037 / \mathrm{a} 0015808$

Fritz, C. O., Morris, P. E., \& Richler, J. J. (2012). Effect size estimates: Current use, calculations, and interpretation. Journal of Experimental Psychology: General, 141(1), 2-18. https://doi.org/10.1037/a0024338

From, L., Olesen, M. H., \& Thomsen, D. K. (2020). Elite athletes are higher on Grit than a comparison sample of non-athletes. Scandinavian Journal of Sport and Exercise Psychology, 2, 2-7. https://doi.org/10.7146/sjsep.v2i0.115111, 1999.

Glerum, J., Loyens, S. M. M., \& Rikers, R. M. J. P. (2020). Mind your mindset. An empirical study of mindset in secondary vocational education and training. Educational Studies, 46(3), 273-281. https://doi.org/10.1080/ 03055698.2019.1573658

Hernández, E., Moreno-Murcia, J., Cid, L., Monteiro, D., \& Rodrigues, F. (2020). Passion or perseverance? The effect of perceived autonomy support and grit on academic performance in college students. International Journal of Environmental Research and Public Health, 17(2143), 1-13.

Hodge, B., Wright, B., \& Bennett, P. (2018). The role of grit in determining engagement and academic outcomes for university students. Research in Higher Education, 59(4), 448-460. https://doi.org/10.1007/s11162-017-9474-y

Jacobs, P. A., \& Newstead, S. E. (2000). The nature and development of student motivation. British Journal of Educational Psychology, 70(2), 243-254. https://doi. org/10.1348/000709900158119

Kannangara, C. S., Allen, R. E., Waugh, G., Nahar, N., Noor Khan, S. Z., Rogerson, S., et al. (2018). All that glitters is not grit: Three studies of grit in University Students. Frontiers in Psychology, 9. https://doi.org/10.3389/fpsyg.2018.01539

Likert, R. (1932). A technique for the measurement of attitudes. Archiv für Psychologie, $140,1-55$.

Macnamara, B. N., \& Rupani, N. S. (2017). The relationship between intelligence and mindset. Intelligence, 64(September 2016), 52-59. https://doi.org/10.1016/j. intell.2017.07.003

Martin, J. J., Byrd, B., Watts, M. L., \& Dent, M. (2015). Gritty, hardy, and resilient: Predictors of sport engagement and life satisfaction in wheelchair basketball players. Journal of Clinical Sport Psychology, 9(4), 345-359. https://doi.org/10.1123/ jcsp.2015-0015

Rutberg, S., Nyberg, L., Castelli, D., \& Lindqvist, A. K. (2020). Grit as perseverance in physical activity participation. International Journal of Environmental Research and Public Health, 17(3). https://doi.org/10.3390/ijerph17030807

Ryan, R., \& Deci, E. (2002). An overview of self-determination theory: An organismic dialectical perspective. In E. L. Deci, \& R. M. Ryan (Eds.), Handbook of selfdetermination research (pp. 3-53). University of Rochester Press.

Schmidt, F. T. C., Nagy, G., Fleckenstein, J., Möller, J., \& Retelsdorf, J. (2018). Same same, but different? Relations between facets of conscientiousness and grit. European Journal of Personality, 32(6), 705-720. https://doi.org/10.1002/per.2171

Sigmundsson, H. (2021). Passion, grit and mindset in the ages 14 to 77: Exploring relationship and gender differences. New Ideas in Psychology, 60(May 2020), 100815. https://doi.org/10.1016/j.newideapsych.2020.100815

Sigmundsson, H., Clemente, F. M., \& Loftesnes, J. M. (2020). Passion, grit and mindset in football players. New Ideas in Psychology, 59.

Sigmundsson, H., Haga, M., \& Hermundsdottir, F. (2020a). Passion, grit and mindset in young adults: Exploring the relationship and gender differences. New Ideas in Psychology, 59(March), 100795. https://doi.org/10.1016/j. newideapsych.2020.100795

Sigmundsson, H., Haga, M., \& Hermundsdottir, F. (2020b). The passion scale: Aspects of reliability and validity of a new 8-item scale assessing passion. New Ideas in Psychology, 56, 100745. https://doi.org/10.1016/j.newideapsych.2019.06.001

Vallerand, R. J. (2008). On the psychology of passion: In search of what makes people's lives most worth living. Canadian Psychology, 49(1), 1-13. https://doi.org/10.1037/ 0708-5591.49.1.1

Vallerand, R. (2010). On passion for life activities: The dualistic model of passion. In M. Zanna (Ed.), Advances in experimental social psychology (pp. 7-193). Academic Press.

Vallerand, R. J., Donahue, E., \& Lafreniere, M. (2011). Passion in sport. In P. Morris, \& T. Terry (Eds.), The new sport and exercise psychology companion (pp. 583-607). Fitness Information Technology.

Vallerand, R. J., \& Miquelon, P. (2007). Passion for sport in athletes. In S. Jowett, \& Lavallee (Eds.), Social psychology in sport (pp. 250-263). Human Kinetics. D.

Vallerand, R. J., Rousseau, F., Grouzet, M., Dumais, A., Grenier, S., \& Blanchard, C. (2006). Passion in sport: A look at determinants and affective experiences. Journal of Sport \& Exercise Psychology, 28, 454-478. 